\title{
Impact of Micro Factors on Women Career Development in Nigeria Hotels
}

\author{
Ihemeje Josephine Ebere, Zuraina BTDato' Mansor, \\ HaslindaBintiHashim \\ Department of Hospitality, Faculty of Economics and Management \\ Universitiputra Malaysia.
}

\begin{abstract}
This article examined the impact of micro factor on the career development of women in hotel industry in Etsako West LGA of Edo State. About 460women in 18 selected hotels in Etsako West LGA were sampled using questionnaire. Multiple regression analysis was applied to analyse the data collected. The results shows that all the dimensions of micro factor; organisational culture $(r=0.185 ; \mathrm{p}<.05)$, family factor $(\mathrm{r}=$ $0.306 ; \mathrm{p}<.05)$ and individual factor $(\mathrm{r}=0.381 ; \mathrm{p}<.05)$ has a significant relationship on career development of women in the studied hotels in Etsako West LGA. Regarding the strength of the relationship, the results shows that the organisational culture has small but positive relationship, family factor have a positive but medium relationship, and the individual factor have a positive, but medium relationship. Results of the micro factor dimensions that contributed to the prediction of the career development of women in hotel industry in Etsako West LGA shows that organizational factor made the highest contribution to career development and as well significant $(\beta=0.756 ; p<.05)$, followed by family factor which is also significant $(\beta=0.182 ; p<.05)$. Individual factor made the lowest contribution but significant $(\beta=0.133 ; \mathrm{p}<.05)$. To this end, this implies that if organizational culture is not favourable, it could have effect on the career development opportunities given to women, thereby influencing the number of women progressing to higher management positions in hotel industry. This suggests that managers of hotel industry should put in place gender friendly organisational policies that could encourage professionalism, including, enforcement of family support programmes that could enhance the career path of women. In view of this, favourable organisation policy, complimented with family support can enhance career development of women in hotel industry. Hence, managers of hotel industry should put in place gender friendly organisational policies that could encourage professionalism and merit rather than discrimination. This will ensure that women who show the required individual skills, competence, and experience could attain their target career aspiration unobstructed.
\end{abstract}

Keywords:-Career development, Micro factor, Hotel industry, Women

\section{INTRODUCTION}

Hotel industry is a service oriented industry that provides food, drinks, accommodation and other auxiliary services to the public for either profit-gain or welfare reasons (Bello and Bello, 2015). The contributions of the industry towards the provision of employment opportunities for individuals are enormous, hence, promoting the Gross Domestic Product (GDP) of many countries (Barbara, et al., 2015; UNWTO, 2011b). Within the global context, hotel industry provides considerable employment opportunities for both men and women (International Labour Organisation (ILO), 2010).However, it was reported that women constitutes reasonable number of labour force in the hotel industry (Verick, 2014; UNWTO, 2011b) but, with little representation at the level of management (Baum and Wally, 2013; Pinar et al., 2011; Zhong, 2006).

Kattara (2005) found that only 153 (13.2\%) of hotel managers in Egypt were women out of a total of 1,161, and only three women in 71 hotels were able to progress to the higher managerial positions. In a research of middle managers in international hotel industry in Jordan, it was reported that only 33 women (16\%) compared to 174 men (84\%) are in the management positions (Masadeh, 2009). In addition, Timo and Davidson's (2005) study on Australian MNCs revealed that about $34.5 \%$ women managers compared to $65.5 \%$ of their men counterparts are in hotel industry. The above findings are consistent with findings in hotel industries in Asia and Middle Eastern countries. According to Li and Leung's (2001), only two women in 77 hotels in Singapore have reached general manager position. Similarly, Ng and Pine (2003) study indicated that out of 72 hotels in Hong Kong, only three women have made it to the general management positions. The situation is not different in Nigeria regardless of the high involvement of women in the Nigerian hotels. A report by National Bureau of Statistics (2015) had it that women dominate the lower echelon such as receptionist, bar staff and cooking assistance in the Nigerian hotel industry. The study of gender ratio of staff in the hotel industry as reported in 
UNWTO (2012) shows that about 56.6\% of women working in Nigerian hotels are working as clerical staff, $34.8 \%$ as service staffs, and just about $34.9 \%$ gets to the management level. Studies conducted in the domain of gender and employment in respect of Nigerian women in hotel industry was done to assess the ratio of women in executive positions (Akinwale, 2013). The study found that no woman manager was represented out of the 153 hotel employees surveyed. These information portraits a negative trends and void of gender balance in placement of equal opportunities for both genders in managerial positions.

Limitations identified in the extant literature about career development of women in hotel industry preclude a more in-depth understanding of the micro factors influencing career development of women in Nigerian hotels (Karatepe and Magaji, 2008). Previous studies in domain of women career development have shown that a variety of micro factors which are unforeseen have predictable influenceson career development of women (Hickey et al., 2012; Robinson and Bornholt, 2007; Patton and Creed, 2006). Though, these studies were not examined in the context of hotel industry in Nigeria. Aside, these studies have taken a narrow view of factors that impact on women career development without considering the micro factors. To the best of my knowledge, very limited studies have taken account of micro factors that are relevant to explaining career development of women in Nigerian hotel industry (KaratepeandMagaji, 2008). In view of this, the focus of this article is to examine dimensions of micro factor that influences career development of women in the hotel industry in Etsako West LGA of Edo State. Aside, the most predicted and relative contribution of dimensions of micro factor to career development of women in the hotel industry in Etsako West LGA of Edo State will be examined.

\section{THEORETICAL FRAMEWORK: MICRO FACTORS INFLUENCING WOMEN CAREER DEVELOPMENT IN HOTEL INDUSTRY}

This study is based on ecological system theory developed by UrieBronfenbrenner in 1979. The theory was used in the field of development psychology to explain how influences within a child's environment affect his growth and development. The theory states that an individual's development occurs from the act of continues mutual interface between the individual, and environmental factors. In order words, there are factors which contribute to an individual 's development at the individual level (Nelson and Veltri, 2011), and factors in the external environment which also influence the individual (Cook, 2012). The context, according to Bronfenbrenner, constitutes four distinct concentric systems: micro, meso, exo, and macro system, each having direct or indirect influence on a child's development.Lately, UrieBronfenbrennerecological system theory had been used to explain the career development of women (Nelson andVeltri, 2011; Rice, 2011; Cook, 2012), however, not in the context of Nigeria hotels. According to Nelson andVeltri (2011), ecological approach helps to identify those factors that influence women careers. The study identified micro factor such as individual factor as factors that contributes to women career development because women career are influenced by a variety of contextual factor which directly or indirectly determines their career choice. Similarly, Rice (2011) posits that there is a distinct interaction of microsystem factor, and women career development. In addition, Cook (2012) asserted that the micro system interactions are most useful when exploring and framing career development for women. The authors contend that there is a significant connection between women and their immediate environment (microsystem). The index in the above information implies that there is complexity of micro factors that influence sustainable career development of women. The micro system in which women interacts directly has a dramatic impact on how they view themselves and their career development (Cook, et al., 2005). Based on previous studies in the area of career development, the following dimensions are assumed as the micro factors that influence women career development.

III.

\section{ORGANIZATIONAL CULTURE}

Organizational culture plays an important role in the career development of women (Shapiro et al., 2008). According to Rasool et al., (2012), organizations that support career development of individuals have impact on individual's career salience such as career satisfaction, career planning and career development. This is supported by Wickramaratne (2013) findings which prove that organizational culture that supports career development have positive impact on employee's general career outcomes. Meanwhile, Wentlingand Thomas (2009) stated that some organizational cultures such as male-dominated culture, lack of support and intimidation from male colleagues have effect on women career development. However, some organizations have begun to develop strategic plans in grooming women for management positions through training and career development (Nchabira, 2013). Cook (2012) argued that change in policies such as family friendly policies, access to mentors and role models, opportunity to network, support from colleagues and devising strategies for increasing salaries will help in women career longevity and career development. In view of the above findings, the present study assumes that organizational culture contributes to career development of women in Etsako West LGA. 


\section{i) Family Factor}

Career development for women is connected with their family responsibility which reduces their opportunities for greater career plan (Wolfinger et al., 2008). In spite of the fact that the participation of women in workforce is on the increase, however, having family responsibilities as wives and mothers have been shown to reduce women's interest, determination and competence to maintain a career while taking care of the family. Consistent with this, studies observed that family factor such as family structure, work-family conflict, and number of children had an adverse effect on women's career development in the sense that being a wife and mother is contributes to career interruptions and slow progression of women particularly at high management level (Cross, 2010).However, evidence shows that women who receive support from their family face less stress and greater career development than women who do not get support from the family because support from spouse has effect on women's career creativity for better performance at work by enhancing their positive mood (BaralandBhargava, 2011). Based on these findings, this study proposed that family factor have influence on career development of women.

\section{ii)Individual Factor}

Individual characteristics is said to play a vital role in the career development of women, as a result improve their encouragement to take more risk and believe in their skills without given up their personality (Ahmad, 2008). Lahti (2013) identified women's own attitudes, perceptions, skills and competences as individual factor shown to play a role in women's managerial career development. The author further stated that women's positive determination and courage help them to advance in their career, mostly if they do not have role models and proper networks. In view of this, the present study hypothesis that individual factor contributes to career development of women.

IV.

\section{PROPOSED MODEL AND HYPOTHESIS}

In view of the above literature, this paper proposed the micro factor model capable of explaining dimensions that impact of career development of women in hotel industry inEtsako West LGA, including, their corresponding hypotheses as shown in Figure 1, and Table1 respectively.

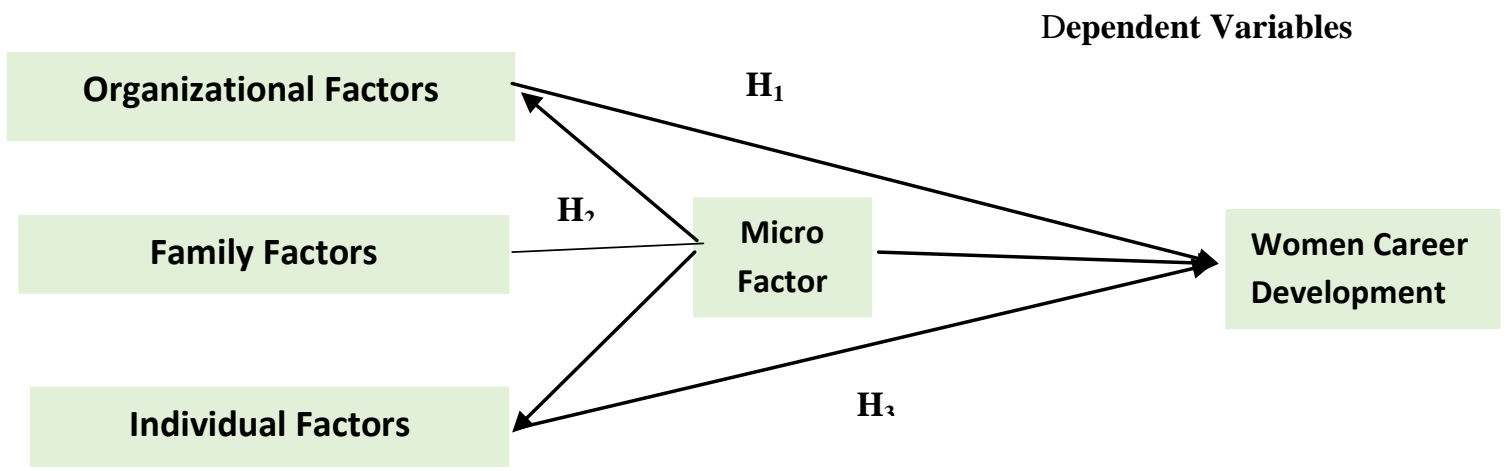

Figure 1: Model of Micro Factor Influencing Women Career Development in Hotel Industry

Table 1: Proposed Hypothesis of Micro Factors Influencing Career Development of Women in Hotel Industry

H1. There is significant relationship between organizational culture and career development of Women in hotel industry in Etsako West LGA.

H2. There is significant relationship between family factor and career development of Women in hotel industry in Etsako West LGA.

H3. There is significant relationship between family factor and career development of Women in hotel industry in Etsako West LGA.

\section{RESEARCH METHODOLOGY}

The research population include 128,654 women that work in hotels in Nigeria. However, the current study was conducted in respect of women working in the hotel industry in 18 selected hotels in the three major towns in Etsako West LGA of Edo State, Nigeria put at about 460. These three towns in Etsako West LGA was chosen because of its strategic location in the local council, and more so in Edo State connecting the Northern and the Southern Nigeria. The touristic resources in these towns, including, its natural resources endowment 
makes it an attractive tourist, and investment destination among both the local, and foreign tourists, including, foreign investors respectively. The presence of a first generation tertiary institution (i.e. Federal Polytechnic Auchi) and the siting of new generation banks in these major towns in Etsako West LGA motivated influx of chains of hotel establishments into the area. The three major towns which include Auchi, Jattu, and Aviele hosts many registered hotels establishments ranging from small size hotels, including, one to five stars hotels establishments. In this study, 18 registered hotels located in these three major towns of Auchi, Jattu, and Aviele, including, the population of women staff is shown in Table 2.

\section{i) Sample Size Determination Approach}

Determining the sample size for this study anchored on the suggestion of Comrey and Lee, (1992) that proposed the rule of 500 as a good sample size for research. Tabachnick and Fidel (1996) upheld this suggestion, hence, opined that a sample size of 100 is poor, 200 is fair, 300 is good, 500 very good, and 1000 is excellent. To determine the sample size of each of the 18 selected hotels used for the study, the present study conceded to the method of proportional allocation suggested in Kothari (1990). The concept of propositional allocation suggested that the sizes of samples from different strata are kept propositional to the sizes of the strata. This implies that if $\mathrm{P}_{\mathrm{i}}$ represents the proportion of the population included in stratum $\mathrm{i}$, and $\mathrm{n}$ represents the total sample size, the number of elements selected from stratum i is $\mathrm{n}$. $\mathrm{P}_{\mathrm{i}}$. As it applies to the present study, the researcher contacted the management of the 18 selected hotels to obtain the total number of women staff in their respective establishments thus; the population $(\mathrm{N})$ size of 546 was obtained as shown in Table 2. The proportion of women staff of the 18 selected hotels (i.e. $\mathrm{P}_{\mathrm{i}} \ldots .5$,) to be drawn from the population $(\mathrm{N})$ of 546 women hotel workers was determined; hence, $\mathrm{P}_{\mathrm{i}} \ldots . .5, / \mathrm{N}$. The researcher determine the sample size per each of the hotels (i.e. $\left.\mathrm{n}_{\mathrm{i}} \ldots . .5\right)$ by multiplying the sample size $(\mathrm{n})$ for this study put at 460 with the proportion of women staff per each of the 18 selected hotels, hence, $\mathrm{n}$. $\mathrm{P}_{\mathrm{i}} \ldots .5$ (See Table 2).

Table 2: Population of Women Staff in Selected Hotels in Etsako West LGA

\begin{tabular}{|c|c|c|c|}
\hline Town & Name of Hotels & $\begin{array}{c}\text { No of Women } \\
\text { Staff }\end{array}$ & Sample Size \\
\hline Auchi & $\begin{array}{ll}\text { - } & \text { Uyi Grand Hotel } \\
\text { - } & \text { Auchi Poly Guest House } \\
\text { - } & \text { Magital Hotel Ltd } \\
\text { - } & \text { Polaris Hotel Ltd } \\
\text { - } & \text { Yak Hotels and Resort } \\
\text { - } & \text { Meremu Hotel and Suite } \\
\text { - } & \text { Presto Hotel Ltd } \\
\text { - } & \text { Regal Rise Hotel }\end{array}$ & $\begin{array}{ll}\text { - } & 38 \\
\text { - } & 32 \\
\text { - } & 26 \\
\text { - } & 30 \\
\text { - } & 38 \\
\text { - } & 38 \\
\text { - } & 33 \\
\text { - } & 31\end{array}$ & $\begin{array}{l}32 \\
27 \\
22 \\
25 \\
32 \\
32 \\
28 \\
26\end{array}$ \\
\hline Jattu & $\begin{array}{ll}\text { - } & \text { Gee Int. Hotel } \\
\text { - } & \text { Randekhi Royal Hotel } \\
\text { - } & \text { Precious Palm Royal } \\
& \text { Hotel } \\
\text { - } & \text { Regal Rise } \\
\text { - } & \text { Best View Hotel and } \\
& \text { Suite } \\
\text { - } & \text { Motrose Motel and } \\
& \text { Resort } \\
\text { - } & \text { Uwele Resort }\end{array}$ & $\begin{array}{ll}\text { - } & 28 \\
\text { - } & 34 \\
\text { - } & 36 \\
\text { - } & 26 \\
\text { - } & 20 \\
\text { - } & 24 \\
\text { - } & 26\end{array}$ & $\begin{array}{l}23 \\
29 \\
31 \\
22 \\
16 \\
20 \\
22\end{array}$ \\
\hline Aviele & $\begin{array}{l}\text { - Meridian Lodge Hotel } \\
\text { and Suites } \\
\text { - } \quad \text { Best View Hotel and } \\
\text { Suite } \\
\text { - Baladi Hotel }\end{array}$ & $\begin{array}{ll}\text { - } & 36 \\
\text { - } & 26 \\
\text { - } & 24\end{array}$ & $\begin{array}{l}31 \\
22 \\
20\end{array}$ \\
\hline
\end{tabular}




\begin{tabular}{|c|c|c|}
\hline $\begin{array}{c}\text { Total Population of Women } \\
\text { Hoteliers }\end{array}$ & $\mathbf{5 4 6}$ & $\mathbf{4 6 0}$ \\
\hline
\end{tabular}

\section{ii)Instrument for Data Collection}

The research instrument used for the present study was adapted and modified from three previous instruments that include Bergman and Hallberg (2002) women workplace culture scale that consists of 21 questions and used to measure organizational culture. Work family conflict scale developed by Carlson et al (2000) was adapted and modified to measure family factor; hence, the scale consists of 9 questions. Individual factor scale that consists of 7 questions was adapted from (Bridgstock, 2007) study. The modified instrument had 37 indicators tentatively distributed to cover 3 dimensions: Organisation Culture, Family Factor, and Individual Factor. The study adopted a 5 point Likert scale ranging from "Strongly disagree" to "Strongly agree" as a response to items in the questionnaire. In order to distinguish between the revised instrument and the version customised for the present study, the latter has been referred to as "Micro Factor Scale for Women Career Development in Hotel Industry" (MFSWCD)" instrument. The MFSWCD instrument was pre-tested with a sample of 40 respondents from the targeted hotels through stratified sampling. Hence, justify the suggestion in Hair et al. (2010) that a minimum of 30 respondents was sufficient for pretesting. After the pre-testing, the questionnaire was administered on the sampled respondents of the 18 selected hotels in the three major towns in Etsako West LGA of Edo State personally by the researcher.

\section{iii) Sampling Technique}

Probability sampling based on probability theory involves the idea of random sampling, however, non-probability sampling is used when probability sampling is inappropriate or impossible to be used (Babbie, 2007), and generalisation of outcome does not matter (Samuel et al., 2003). As it applies to the present study, it was practically impossible to access the nominal register of women staff from the 18 selected hotels, hence, the researcher opted for non-probability sampling with convenience sampling technique. Convenience sampling technique is a non-probability sampling method that offered no inclusion of criteria prior to selection of participants from the target hotels (Coakes et al., 2009). The author further affirmed that the method involves getting participants wherever the researcher can find them within the hotel premises, hence, very convenient, cheap and fast. In view of this, the researcher personally visited each of the 18 targeted hotels and, thus, administered the structured questionnaires to every female staff until the sample quota per hotel as shown in Table 2 was met, and the datacollectedwere analysed using multiple regression.

\section{RESULTS AND DISCUSSION}

Psychometric test of the MFSWCD instrument was tested, and the results of the reliability coefficient of individual items met the threshold Cronbach alpha $(\alpha)$ value of .7. This suggests that all the items measures underlying dimensions consistently (Coakes et al., 2009). The composite reliability score for each of the three aggregate dimensions of micro factor ranges from 0.811 - 0.966. Hence, Organisational Culture $(\alpha=0.811)$, Family Factor $(\alpha=0.966)$, and Individual Factor $(\alpha=0.919)$ as shown in Table 3

Table 3: Reliability of Dimensions and Items of Micro Factors Influencing Career Development of Women in Hotels in Etsako West LGA of Edo State

\begin{tabular}{lcc} 
Dimensions & $\begin{array}{c}\text { Final } \\
\text { Alpha }\end{array}$ & Cronbach \\
\hline Organisational Culture & .811 \\
Family Factor & .966 \\
Individual Factor & .919 \\
\hline \hline
\end{tabular}

i) Relationship between the Dimensions of Micro Factor and Career Development of Women in Hotel Industry

The relationship between the dimensions of micro factors and career development of women in the hotel industry in Etsako West LGA of Edo State was examined for its direction and strength. The results as shown in Table 4 shows that the three dimensions of micro factor; organisational culture $(\mathrm{ORC})(\mathrm{r}=0.185 ; \mathrm{p}=0.000)$, family factor $(\mathrm{FAMF})(\mathrm{r}=0.306 ; \mathrm{p}=0.000)$ and individual factor (INDF) $(\mathrm{r}=0.381 ; \mathrm{p}=0.000)$ has a positive 
and significant relationship with career development (CAD) of women. Regarding the strength of the relationship, the results shows that the organisational culture has small and positive relationship, family factor have medium and positive relationship and the individual factor as well have a positive and medium relationship. Therefore, the alternate hypothesis were accepted which states that there is a significant relationship between the dimensions of micro factor (organizational culture, family factor, and individual factor) and career development of women in Nigerian hotel industry.

Table 4: Pearson Correlations of Micro, and Macro Factor and Career Development

\begin{tabular}{llll}
\hline \hline Variables & $\mathbf{R}$ & $\mathbf{P}$ & Level \\
\hline Career Development (CAD) & -- & -- & -- \\
Organizational Culture (ORC) & $0.185^{* *}$ & 0.000 & Small \\
Family Factor (FAMF) & $0.306^{* *}$ & 0.000 & Medium \\
Individual Factor (INDF) & $0.381^{*}$ & 0.000 & Medium \\
\hline \hline
\end{tabular}

** Correlation is significant at the 0.01 level (2-tailed).

\section{ii)Relative Contributions of Dimensions of Micro Factor to Career Development ofWomen in Hotel Industry.}

The micro factor dimensions that contributed to the prediction of the career development of women in hotel industry in Etsako West LGA was examined using $(\boldsymbol{\beta})$ as shown in Table 5.

Table 5: Relative Contribution of the Dimensions Micro Factor to Career Development of Women Table 5 shows that individual factor made the highest contribution to career development and as well significant $(\beta=.360 ; p<.05)$, followed by organizational culture which is also significant $(\beta=.298 ; p<.05)$. Family factor made the lowest contribution but significant $(\beta=.047 ; \mathrm{p}<.05)$.

\section{ODISCUSSION OF FINDINGS}

The results of the relationship between dimensions of micro factor and career development revealed that organisational culture, family factor and individual factor has a positive but significant relationship on career development among women in the hotel industry in Etsako West LGA. This implies that the more the culture of hotel industry in in Etsako West does not recognise importance of women in the higher positions, the less the opportunity for women to get to the top in their hotel career. Likewise, the higher the responsibility of family bore by women, the less the opportunity for them to achieve their career development goals. However, individual factor has a positive and significant relationship. This implies that the more women develop their individual traits, the more likely they can advance more to higher positions in the hotel industry.

\begin{tabular}{|c|c|c|c|c|}
\hline Predictor & $\begin{array}{l}\text { Unstandardized } \\
\text { coefficient } \\
\text { B }\end{array}$ & $\begin{array}{l}\text { Standardized } \\
\text { Coefficient } \\
\beta\end{array}$ & $\mathbf{t}$ & Sig \\
\hline (constant) & 54.164 & & 15.217 & .000 \\
\hline Organizational Culture (ORC) & 293 & 298 & 5.503 & .000 \\
\hline Family factor (FAMF) & .046 & .047 & 786 & .003 \\
\hline Individual factor (INDF) & .580 & .360 & 5.875 & .000 \\
\hline
\end{tabular}

The result of the present study is in consonance with the findings of some literature in the domain of career development.Wickramaratne (2013), and Rasool et al (2012)studiesfound a positive significant relationship between organizational culture and women career development. Other studies posit that organization structure and culture have barriers thatinfluence women career development (Wood, 2011; Powell and Graves, 2003). Based on the above, the conclusion that could be drawn is that the culture of individual organisation should be treated on their merit in respect of its impact on career development of women.

In respect of family factor, the result of the present study shows that family factor has a positive and significant relationship on career development among women in the hotel industry in Etsako West LGA of Edo State. This result supports some previous literature in domain of career development. Ahmad (2008) posits that family factor does have positive influences on career development of women. This result is supported in Ezzedeenand Ritchey (2008); Friedman andGreenhaus (2000), hence, they argued that there is a significant positive relationship between family support and women career development. Other studies such as Mayrhofer et al. (2008); Tharenou (2005) affirmed that family obligations affect women career development. Based on the 
above, the conclusion that could be drawn is that the extent of support received by women from their respective families determines their career prospect.In respect of individual factor, the results of the present study further shows that there is positive correlation between individual factor and career development among women in hotel industry in Etsako west LGA. This finding is in consonance with previous literature, hence, Wentlingand Thomas (2007) and Adler et al. (2000) pointed that there is significant positive relationship between individual factors and women career development. Wickramaratne (2013) argued that most women who aspire for superior positions tend to adapt to masculine personality in order to prove their competences because women who show feminine traits are considered weak; and those who show strong masculine traits are not likely to face adverse challenges in their organization which impacts positively on their chances of promotion and career development. Ahmad (2008) stated that women need to be encouraged to take more risk and believe in their skills. In view of the above, it can be concluded that women adaptation to masculine personality; including, risk taking and believing in their skills could enhance their career prospects.

The results of the relative contribution of dimensions of micro factors to career development among women in hotel industry shows that individual factor made the greatest contributions to career development. This implies that achieving career success in hotel industry among women depend on variety of individual factors. This result is in support of previous literature, hence, Lahti (2013) asserted that women's attitudes, perceptions, skills and competences are some individual factor that play important role in women's managerial career development. Organisational culture had the secondsignificantrelative contribution to career development of women. The result validated in Kanter (1993) theory of absolute number and the way dominant members of an organisation determine its climate as a result of unfavourable organisational culture. Wentling\& Thomas (2009) pointed that organizational cultures such as male-dominated culture, lack of support and intimidation from male colleagues have effects on women career development.Furthermore, family factor made the third significant contribution to career development. This implies that favourable family factor could enhance the career development of women in hotel industry. The results supported previous literature, hence, Ahmad (2008) find that family can have positive or negative influences on individual women's career attitudes, behaviours, and development

\section{PRACTICAL / POLICY IMPLICATIONS}

Literature reveals that various dimensions of micro factors influence women career development. Thus, examination of the effects of these dimensions on career development of women in hotel industry in Etsako West LGA, including the relative contributions of these individual dimensions to career development is timely. This may be useful to authorities in charge of hotel industry to know how best to manage career development among women in the hotel industry. To this end, organisational culture of hotels, family factors and individual factor influences career development of women in hotel industry. This implies that unfavourable organisation policy reduces career development opportunities available to women. Furthermore, unsupportive family influences can impedewomen aspiration towards high career development prospects in hotel industry. In addition, lack of adequate personality traits affects the competence of many women to advance to higher position in hotel industry. Hence, managers of hotel industry should put in place gender friendly organisational policies that could encourage professionalism and merit rather than discrimination. This will ensure that women who show the required individual skills, competence, and experience could attain their target career aspiration unobstructed. Family support programmes that could enhance the career path of women should be encouraged and enforced for implementation in the Nigeria private sector, including, the hotel industry.

The results further identified that individual factor made the greatest contributions to career development in the context of women in hotel industry in Etsako West LGA. This implies that achieving career success in hotel industry among women depend on variety of individual factors. Hence, women in hotel industry are expected to possess the right work attitudes, skills, competences, personality, interest, self-concept, and esteem for them to attain their career aspiration. In view of this, it is suggested that managers of hotel industry should organise on the job training that could develop women individual personal skills and competence, hence, empowering them for career prospects.Meanwhile, organisational culture of hotels in the study areas did also have relative contribution to career development of women. Favourable organisation policy can enhance career development of women in hotel industry. Therefore, managers of hotel industry should put in place gender friendly organisational policies that could encourage professionalism and merit rather than discrimination.. Furthermore, family factor have significant but little contribution to women career development. In view of this, family members mostly spouses of women in hotel industry should offer appropriate support by providing emotional support, instrumental aid and greater flexibility which enhances women's career creativity for better performance at work. 


\section{REFERENCES}

[1] Ahmad, A. (2008). Job, Family and Individual Factors as Predictors of Work-Family Conflict. The Journal of Human Resource and Adult Learning, 4, (1), 57-67.

[2] Akinwale, O. (2013). Gender Differences in Employment in the Hotel Industry in Lagos State. Journal of Hospitality Management, 31, (1), 22-43.

[3] Babbie, E. (2007). The Practice of Social Research (11th ed.). Belmont, CA: Wadsworth/ Thomson.

[4] Baral, R., and Bhargava, S. (2011). Examining the Moderating Influence of Gender on the Relationships Between Work-Family Antecedents and Work-Family Enrichment. Gender in Management: An International Journal, 26, (2), 122-147.

[5] Barbara, B., Eric, O., and Colleen, Z. (2015). African Economic Outlook. Retrieved from Nigeria 2015: www.africaneconomicoutlook.org, October, 6.Management Journal, 24, (11), 1107.

[6] Bello, Y. O., and Bello, M. B. (2015). Lodging Service Management and Administration, Theory and Practice. Benin: Diamond Publishing House.

[7] Bergman, B., and Hallberg, L. R. M. (2002). Women in a Male-dominated Industry: Factor Analysis of a Women Workplace Culture Questionnaire Based on a Grounded Theory Model. Sex Roles, 46, (9-10), 311-322.

[8] [Coakes, S. J., Steed, L., and Ong, C. (2009). Analysis Without Anguish: SPSS Version 16.0 for Windows. Australia: John Wiley and Sons Ltd.

[9] Comrey, A. L. and Lee, H. B. (1992). A First Course in Factor Analysis. New Jersse: Erlbaum.

[10] Cook, E. P., Heppner, M. J., and O'Brien, K. M. (2005). Multicultural and Gender Influences in Women's Career Development: An Ecological Perspective. Journal of Multicultural Counseling and Development, 33, (3), 165-179.

[11] Cook, E. P.(2012). Understanding People in Context: The Ecological Perspective in Counseling. Alexandria, VA: American Counseling Association.

[12] Cross, C. (2010). Barriers to the Executive Suite: Evidence from Ireland . Leadership and Organization Development Journal, 31, (2), 104-119.

[13] Ezzedeen, S.R. and Ritchey, K. G. (2008). The Man Behind the Woman: A Qualitative Study of the Spousal Support Received and Valued by Executive Women . Journal of Family Issues, 29, (9), 11071135.

[14] Hickey, N., Harrison, L. and Sumsion, J. (2012). Using a Sociological Framework to Understand the Career Choices of Single- and Double-degree Nursing Students and Double-degree Graduates. ISRN Nursing.

[15] International Labour Organisation (ILO). (2010). Development and Challenges in the Hospitality and Tourism Sector; Issues Paper for Discussion at the Global Dialougue Forum for the Hotels, Catering, Tourism Sector. Geneva: ILO.

[16] Kanter, R. (1993). Men and Women of the Corporation (2nd ed.) . New York : Basic Books.

[17] Kattara, C. (2005). Determinants of Managerial Career Success: Evidence and Explanation of Male/Female Differences . Journal of Management, 24, (6), 673-92.

[18] Kothari, C. .. (1990). New Age Research Methodology; Methods and Techniques (2nd Ed). New Delhi: New Age International (P) Limited.

[19] Li, L., and Leung, R. (2001). Female Managers in Asian Hotels: Profile and Career Challenges . International Journal of Contemporary Hospitality Management , 13, (4), 189-196.

[20] Mayrhofer, W., Meyer, M., Schiffinger, M. and Schmidt, A. (2008). The Influence of Family Responsibilities, Career Fields and Gender on Career Success: An empirical Study . Journal of Managerial Psychology, 23, (3), 292-323.

[21] Nchabira, K. M. (2013). Barriers to Women Career Progression in Kenya's Civil Service .Kenya:Doctoral Dissertation, Jomo Kenyatta University of Agriculture and Technology.

[22] Nelson, K., and Veltri, N. (2011). Women in information technology careers: A person-process-contexttime framework. European Conference on Information Systems (ECIS) (p. 53). ECIS.

[23] Ng, C. W., and Pine, R. (2003). Women and Men in Hotel Management in Hong Kong: Perseptions of Gender and Career Development Issues. Hospitality Management, 22, (1), 85-102.

[24] Patton, W., and Creed, P. A. (2006). Developmental Issues in Career Maturity and Career Decision Status . The Career Development Quarterly, 49, 251-336.

[25] Pinar, M., McCuddy, M. K., Birkan, I. and Kozak, M. (2011 ). Gender Diversity in the Hospitality Industry: An Emperical Study in Turkey . International Journal of Hospitality Management, 30, (1), 7381.

[26] Powell, G. N., and Graves, L. M. (2003). Women and Men in Management .Newbury : Park, CA.

[27] Rasool, S., Kiyani, A. A., Aslam, M. J., Akram, M. U. and Rajput, A. A. (2012). Impact of organiational culture on employee's career salience: An emperical study of Banking Sector in Islamabad, Pakistan. International Journal of Business and Social Science, 3, (7), 1-12. 
[28] [Rice, D. N. (2011). The Career Experiences of African American Female Engineers . Texas: Doctoral Dissertation, Texas A \& M University.

[29] Samuel, M.D., Joly, D.O., Wild, M. A., Wright, S.D., Otis, D. L., Werge, R. W., Miller, M.W. (2003). Surveillance Strategies for Detecting Chronic Wasting Disease in Free-Ranging Deer and Elk. CWD Survelliance Workshop USGS .Madis, Wisconsin: National Wildlife Health Centre.

[30] Shapiro, M., Ingols, C. and Blake-Beard, S. (2008). Confronting career double binds: implications for women, organizations, and career practitioners. Journal of Career Development, 34, (3), 309-33.

[31] Tabachnick, B. G., and Fidell, L. S. (2007). Using Multivarite Statistics (5th ed.). Boston: Allyn and Bacon.

[32] Tharenou, P. (2005). Does Mentor Support Increase Women's Career Advancement mMre than Men's? The Differential Effects of Career and Psychosocial Support . Australian Journal of Management, 30, (1), 77-109.

[33] United Nations World Tourism Organization . (2012). Gender and Tourism; Regional Seminar on Responsible Tourism: Opprtunities for Women and Youth in Nigeria .Genever: UNWTO.

[34] United Nations World Tourism Organization (UNWTO). (2011b). Global Report on Women in Tourism. Joint Report by World Tourism Organization (UNWTO) and United Nations Entity for Gender Equality and the Empowerment of Women. Genever: UNWTO.

[35] [36] Verick, S. (2014). Female Labor Force Participation in Developing Countries. London: IZA World of Labor.

[36] Wentling, R. M. \& Thomas, S. (2009). Workplace culture that hinders and assists the career developement of women in information technology. Journal of Information Technology, Learning and Performance, 25(1), 25-42.

[37] Wentling, R. M., and Thomas, S. (2007). The career development of women executives in information technology. . Journal of Information Technology Management, 18, (1), 33-48.

[38] Wickramaratne, W. R. (2013). Role of Career Development Culture and Senior Management Support in Career Development . International Journal of Arts and Commerce, 2, (6), 79-81.

[39] Wolfinger, N. H., Mason, M. A., and Goulden, M. (2008). Problems in the Pipeline: Gender, Marriage, and Fertility in the Ivory Tower. The Journal of Higher Education, 79, (4), 388-405.

[40] Wood, D. (2001). Winners and Losers of Participation in Praxis: A Case Study of Strategic Tourism Planning in Australia's North West. Shanghai, China: The World Planning Schools Congress.

[41] Zhong, Y. (2006). Factors Affecting Women"s Career Advancement in the Hospitality Industry. Perceptions of Students, Educators, and Industry Recruiters . Journal of Language, Technology and Entrepreneurship, 3, (12),23-56 